\title{
COMPARATIVE LAW AND CONFLICT OF LAWS IN GERMANY
}

\author{
MAX RHEINSTEIN*
}

I

$\mathrm{I}^{\mathrm{s} C}$

EGAL science is confined to country jurisprudence, the scientific borders coinciding with the political ones. A humiliating, unworthy form for a science!'

In I924 Hermann Isay placed these words of Rudolf v. Jhering ${ }^{\mathrm{I}}$ at the head of his pamphlet The Isolation of German Legal Thought. It was dedicated "To the Young German Lawyers," and it stirred deeply Germany's legal profession.

This suggestive little book warned German legal science against the danger of getting into a blind alley, of becoming lost in arid positivism.

"Legal science is a normative science. It deals with the regulation of general life. Ultimately such a task cannot be achieved unless founded upon a philosophy, its rules cannot be applied except on such a basis, if the law is to be elevated, in practice and theoretical reflection, above the level of mere empiricism. When one regards the mind of German lawyers from this viewpoint, one cannot suppress a feeling of dismay. The practitioners rarely concern themselves with the fundamentals of the law or devote conscious reflection to the nature of the law; for them, legal philosophy is out of the question. In the theoretical fields of legal science, the situation is not very different. Positivism, sometimes a very dull positivism, is supreme."

These harsh words were born out of polemic, and are therefore naturally exaggerating, but they are by no means untrue in their substance. One of the principal sources of this evil, so Isay stated, was the isolation of German legal thought, its deliberate seclusion from the flow of legal thought in the other parts of our civilized world. What was needed, so he concluded, was fertilization by foreign thought with consequent comparison, critique, evaluation.

German legal science of the pre-war period was essentially dogmatic. Its attention was focussed upon one task, the interpretation of the actual German statute law, especially the Civil Code, as the basis of the Private

* Visiting Assistant Professor, University of Chicago Law School, formerly Privat-dozent, University of Berlin; Member of the Research Staff of the Kaiser Wilhelm Institute of Foreign and International Private Law.

I v. Jhering, The Spirit of the Roman Law (5th ed.), I5. 
Law system. This dogmatic jurisprudence had been raised to the highest possible summit of development. It had cultivated a refined technique in extracting from the rules of the codes and statutes the appropriate answers for the innumerable problems of life; it had brought together all the many rules into a system of admirable logical consistency, regarding the legal order as a closed unity within which each rule occupies its proper place. It was an imposing structure, and the German jurists were busy primarily with its interior refinement, splitting up concepts through more and more subtle distinctions, or investigating whether each rule had found its quite proper place. Definition and refinement of concepts, search for the proper systematical placement, these were the problems which mainly occupied this dogmatic legal science of the pre-war years. The close association between legal science and legal practice, so characteristic for Germany, fortunately prevented dogmatics from becoming sterile. In spite of its conceptualism, German dogmatic jurisprudence has accomplished much for Germany's legal life. It revealed to the German jurists the contents of the new laws of the young German Empire, and it presented to them its richness in the imposing form of a beautifully organized and articulated structure, which was therefore clear and easy to remember. It is the merit of this dogmatic science, that to the German legal mind the mass of legal rules appears as an organic whole, that the German jurists never lost their orientation amidst the flood of new statute law and accompanying case law that came upon them. But the German dogmaticians worked inside of the legal structure, which they accepted as given. They treated the materials as they were furnished to them by the legislator. It was unusual to regard the material critically, to question the values of the given rules or even their appropriateness, and it was more than unusual to question their foundations. It was a narrow field of activity within which masterly work was done. Just as these dogmaticians cared little for philosophical evaluation, so they cared little for a comparison with foreign legal thought. It was the accepted duty of German legal science to observe and to explain the German law from within; it paid little attention to the world outside.

Of course, such an attitude was not without exceptions. Certainly, there were scholars who took a broader view. There were some men, such as $v$. Jhering in his later years and Josef Kohler, the most universal genius among the German jurists of that time, who were striving for the high aim of a "general jurisprudence" intended to embrace the legal phenomena of all peoples and of all times in one great view, of a "universal legal history" as a part of an idealistic history of mankind, imbued with 
the ideal of progress. ${ }^{2}$ Building on the foundations laid by Albert Hermann Post $^{3}$ and others, in the Zeitschrift fïr vergleichende Rechtswissenschaft, ${ }^{4}$ Kohler and his "school" particularly cultivated the so-called "Ethnological Jurisprudence," the knowledge of the laws of primitive and halfcivilized nations, or of civilizations different from our own. A great many valuable studies on the laws of widely different times and tribes, of the Hottentots and the Wahehe, the Maori and the Eskimos, of China and of the Talmud, of Babylonia and of the Incas, are the fruit of their endeavors, which culminated in the attempt of a Universal Legal Historys for which Kohler sketched the outline and wrote the first parts, ${ }^{6}$ but which was destined to remain a fragment.

Modern foreign laws, however, were not altogether neglected. The growing foreign trade of the Empire necessitated, for mere practical reasons, some concern with the laws of the countries with which German trade was developing. The thirteen monumental volumes of the Commercial Laws of the World ${ }^{7}$ are a memorable result of these activities. International lawyers united with interested scholars in the "International Association for Comparative Law and Economics."

But all these activities, considerable though they were, had little influence upon the German law itself. The scholars, fascinated by their high, too high ends, cultivated a sort of general jurisprudence or Ethnological Jurisprudence. The international practitioners were interested in one or the other foreign law. But very few men regarded critically Germany's

2 Cf. Josef Kohler Bibliographie (I93I), esp. ns. xo4-435.

3 Post, Einleitung in eine Naturwissenschaft des Rechts (I872); Die Geschlechtsgenossenschaft der Urzeit und die Entstehung der Ehe (1875); Der Ursprung des Rechts. Prolegomena zu einer allgemein vergleichenden Rechtswissenschaft ( 1876$)$; Die Anfänge des Staatsu. Rechtslebens (I878); Bausteine für eine allgemeine Rechtswissenschaft auf vergleichendethnologischer Basis (I880); Afrikanische Jurisprudenz (2 vols. 1887).

4 Review of Comparative Legal Science; it was founded in 1877 by F. Bernhöft and G. Cohn; it is now edited by Leonhard Adam.

5 Allgemeine Rechtsgeschichte in Hinneberg's Die Kultur der Gegenwart (IgI4).

${ }^{6}$ Die Anfänge des Rechts und das Recht der primitiven Völker; Das Recht der orientalischen Völker, 49 fi.

7 Handelsgesetze des Erdballs (founded by O. Borchardt, edited by J. Kohler, F. Meyer, H. Dove, H. Trumpler, G. Maas, Igo6-I908); English edition: The Commercial Laws of the World (rgrr); French edition: Lois Commerciales de L'Univers (Igrr).

8 Internationale Vereinigung für Vergleichende Rechtswissenschaft und Volkswirtschaftslehre; it was founded in I894 by Felix Meyer, judge of the Appellate Court of Berlin, a man of great activity and manifold interests. The Association edited a periodical "Blätter für Vergleichende Rechtswissenschaft und Volkswirtschaftslehre" (I905-I926), and a meritorious Yearbook (Jahrbuch der Internationalen Vereinigung für Vergleichende Rechtswissenschaft und Volkswirtschaftslehre, I895-I9I9). 
own law in the mirror of foreign thought, very few made use of the treasure of foreign ideas for the better understanding or development of their own law.

It was only in some particular fields that such a use was made, especially in the comparatively new subjects of copyrights and industrial property, where Josef Kohler made fruitful use of the older, more progressive French doctrine for building up the new German law of copyrights, patents, and unfair competition.9 A peculiar situation prevailed in the field of Criminal Law. In rgo2, the reform of the German Criminal Code, not yet completed, was initiated. The undertaking was put on the broadest scientific basis. Upon the suggestion of the Imperial Ministry of Justice, a group of eminent scholars wrote a Comparative Treatise on German and Foreign Criminal Law, ${ }^{\text {xo }}$ an imposing work, critically sifting the rich foreign material and preparing it for the German legislator. The International Criminalistic Association, ${ }^{\text {xx }}$ founded in 1889 by Franz v. Liszt, Prins, and van Hamel, uniting in one organization the reformers of all countries, created an international forum and a powerful movement for criminal law reform. Yet theory and practice of the actual criminal law of Germany were scarcely influenced.

Political science, of course, never lost contact with foreign thought, ${ }^{\mathrm{I2}}$ but constitutional doctrine, under Paul Laband's leadership,,$^{x 3}$ uncritically interpreted the texts of the constitutions of the Empire and the component states. The German science of administrative law had been founded by Otto Mayer, upon the model of the highly developed Administrative Law of France. ${ }^{\mathrm{I}}$ But neither Otto Mayer in his later works nor his successors followed the considerable progress of French Administrative Law science.

The situation in the main field of German legal science, Private Law, is clearly shown by the outward appearance of the literature of the first decade after the Civil Code of August 24, 1896 , came into force on January I, I900. We find a striking indifference towards foreign law. None of the great treaties of the first period of the Civil Code, Dernburg, ${ }^{15}$ Cosack, $^{16}$

9 Cf. Joseph Kohler Bibliographie (I93I), ns. 830-rozo.

to Vergleichende Darstellung des deutschen und ausländischen Strafrechts (I909).

Ix Internationale Kriminalistische Vereinigung (Mitteilungen 1889 ff.). I9I4).

Is Cf. esp. the standard work, Georg Jellinek, Allgemeine Staatslehre (Ist ed. Igoo) (3d ed.

13 Des Staatsrecht des Deutschen Reiches (1876-I882) (5th ed. I9II-I9I4).

14 Deutsches Verwaltungsrecht ( $1895-1896)$.

×s Das Bürgerliche Recht des Deutschen Reichs und Preussens (I898-I905).

${ }^{16}$ Lehrbuch des deutschen Bürgerlichen Rechts (I898, I900). 
Endemann, ${ }^{17}$ Enneccerus, ${ }^{18}$ none of the big commentaries, ${ }^{19}$ almost none of the monographs which play such an important rôle in German legal literature, contains substantial references to foreign law. Not only the technical literature of the great foreign systems attracted little interest, but even the philosophical and the important methodological discussions of the time, especially in France, were paid little attention, though there were some exceptions, such as the so-called Free-Law-School where Kantorowicz made fruitful use of Geny's ideas. ${ }^{20}$

What were the reasons for this attitude? Certainly not an ignorance of foreign languages, as one might at first think. The German jurists, educated in "gymnasiums," almost all had a reading knowledge of French, and many of English as well. And that difficulties of language are not insurmountable, where there exists a desire for knowledge, is shown by the considerable number of French, English, and, recently, also Spanish translations of German legal writings. The reasons must be sought for deeper. They are found in the general character of the time as it presented itself to the German lawyers at the turn of the century. After hard, long efforts and bloody sacrifices, the political unification of the German nation had been finally achieved. The political unification had not immediately brought the unification of the law. That had to be achieved by another long, gradual process, which culminated in the Civil Code of the German Empire. The preparations for this great work, which was to create a new law for the young Reich, occupied all the forces of the German jurists. And, when the Code stood there perfected, legal science had to make it applicable in practice, to explain the difficult text, to develop its leading principles, to unfold the system of the new law, to state it clearly and to apply it to the manifold problems of life. It was a great task, keeping busy all the legal forces for many years.

Of course, it was not inevitable that these tasks were to be performed in isolation. On the contrary, one might have thought that particularly the codifying legislator would have found valuable suggestions in comparative law. But comparative law was only applied to the many different laws which prevailed in Germany before the Code. ${ }^{2 x}$ Foreign experiences

${ }^{27}$ Lehrbuch des Bürgerlichen Rechts (x896).

${ }^{88}$ First edition by Enneccerus and H. O. Lehmann, Das Bürgerliche Recht (1898, 1900).

s9 Staudinger's Kommentar (Ist ed. I898-I903); Planck's Kommentar (Ist ed. I898-I902); Kommentar zum Bürgerlichen Gesetzbuch von Gareis-Oertmann-Biermann-Opet-v. BlumeFrommhold-Niedner (I898-I906); Kommentar von Hölder-Schollmeyer-A. B. Schmidt (I900, xو07).

${ }^{20}$ Der Rampf um die Rechtswissenschaft (Igo6), published under the pseudonym Gnaeus Flavius; Aus der Vorgeschichte der Freirechtslehre (I925).

${ }^{2 x}$ The legislator very often had to choose between legal institutions of Germanic origin, advocated by the "Germanistic school" (Otto Gierke) and those of Romanistic origin. 
were used neither by the draftsmen of the Code nor by its interpreters. They could not do it, because it required a knowledge, based on elaborate studies of foreign laws, and the necessary time and effort were not available. In Germany, the same phenomenon was observed as in the French Ecole des interprêtes, where the French jurists of the first decades of the Code Napoleon had tried to interpret it wholly out of itself (from Troplong and Desmolombe to the thirty-three volumes of the work of the Belgain Laurent). ${ }^{22}$ There were but few scholars who had foreseen this danger and had warned against it. ${ }^{23}$

But, this is no sufficient explanation. If a real need for a broader outlook had been felt, it would have been attempted, even in a time where all the juristic forces were so thoroughly absorbed. Such a need, however, was not felt. Comparative Law in the proper sense means an observation of one's own law from outside, in order to evaluate it critically. But the time was uncritical, in Germany as well as abroad. It was a satisfied and happy time with people believing in evolution and progress. It was so everywhere, especially in Germany. ${ }^{24}$ The Empire was steadily rising,

$2 z$ It is significant that in France a new legal method was initiated by a foreign stimulus. From Napoleon's times, the French Code was in force in the parts of Prussia, Hesse, Bavaria, and Oldenburg situated on the left bank of the Rhine. A German translation was in force in the Grand-Duchy of Baden. In 1808 a Heidelberg professor of Roman Law, Zachariae v. Lingenthal, published a book in which he treated the French law in the systematic manner of the German Pandectists. Two French jurists, Aubry and Rau, published in $\mathrm{r}_{3} 8 \mathrm{8}-47$ a French revision of this work, which immediately became the leading French treatise, its method being followed by the later French Private Law treatises.

${ }^{23}$ Zitelmann, Die Gefahr des BGB für die Rechtswissenschaft (I896).

24 In other countries, too, the interest in Comparative Law was not too deep. But it had, at least in some places, more influence on the development of the respective municipal laws.

It was natural that the German-speaking jurists of Austria and Switzerland followed very carefully the development of the law of Germany, and that it intensely influenced their own laws, whereas in Germany, "Austrian and Swiss legal thought received scant attention. Only a few authors, among them the "Tübingians," v. Rümelin and $\mathrm{Ph}$. Heck, who were striving to escape from the traditional "conceptual jurisprudence" and who later became the successful protagonists of a new German legal methodology, felt stimulated by the Swiss Civil Code of r907, and used it for their work in the German Law (cf. Rümelin, Das schweizerische Zivilgesetzbuch und seine Bedeutung für uns [rgo8]).

French and Italian legal thought also were generally positivistic and dogmatic. But their isolation was not so great. In France, the preparation of the new German Code was closely followed. Raymond Saleilles especially had brought it and the most important of its new ideas to the knowledge of the legal world of France (Essai d'une thérie générale de l'obligation d'après le projet du Code civil allemand (I8go, rgor). Introduction à l'étude du Code civil allemand (1904). Through him, they exercised considerable influence upon French legal science and practice, as e.g. the idea of responsibility for risk, as it was developed in the German

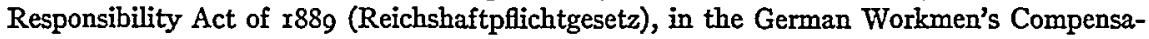
tion Laws (cf. Saleilles, Accidents du travail et la responsibilite civil [1897]), and then in the German Code. The German land registry system, the German doctrine of legal acts, the new German forms of commercial companies, attracted much interest in France. Planiol's standard 
politically and economically. It was steadily gaining in wealth, influence and power. Thus, one was not troubled by the disquieting question: What price institutions? One took them for granted, one worked on their further elaboration. Only a few outsiders, mostly socialists, like Bebel or Karl Menger ${ }^{25}$ cared to question the happy new achievements. Positivism reigned. The description by Isay, quoted at the beginning of this article, was, except for its exaggerations, not untrue. But the very moment he wrote, a movement to break down the narrowness was already under way.

The time for the new movement was ripe. The examination of the Civil Code had been exhausted and the task of its interpretation was essentially finished. It was difficult to find new things in it by the old method. The forces of jurisprudence were free for new work.

II

It was for good reasons that German jurists turned to a critical examination of the German law, and further to a comprehensive study of "law" in general, viz., to comparative law. With the loss of the war and with the revolution, the firm structure of the Empire, the political institutions the German jurists had taken for granted, had collapsed. It was impossible to approach the new situation with the same positivism with which one had treated the old law, and to put oneself wholly inside it

students' text book on the French Private Law (Traite elementaire de droit civile, [I899, Irth ed. I928]) very skillfully uses foreign laws to explain more clearly the peculiarities of French law, contrasting its institutions with those of other countries, especially with those of Germany? and thus critically evaluates the French law and trains the French law students in the comparative law attitude. For many years, the Societe de droit compare had followed and published in the "Annuaire de législation étrangère" ( 1872 ff.) important legislative changes in foreign laws, in order to use them as materials for French legislative reforms. For the same purpose a "Comité de législation étrangère et de droit international" was founded in the French Ministry of Justice.

In Italy, it was especially the German science of civil procedure that won attention, as it had been built up by v. Bethmann-Hollweg, v. Bülow, Hellwig, v. Wach and others. Mortara, Carnelutti, Calamandrei, and a great many younger scholars, built up an Italian science of procedure, using the German doctrines very fruitfully. Similarly Vivante referred to German commercial law in his standard treatise on Italian commercial law, whose legislative basis, the Italian Commercial Code of $\mathbf{r 8 8 2}$, is to a large extent based upon the (old) German General Commercial Code of I86r. Italy's general private law science was and is not only deeply influenced by France, whose code is almost identical, but also by German legal doctrine.

German commercial law was influential in the Netherlands; German general legal doctrine exerted some effect in the Scandinavian countries, and even in English analytical jurisprudence, though not always with happy results (cf. Rheinstein, Die Struktur des vertraglichen Schuldverhältnisses im anglo-amerikanischen Recht [1932], 238 and ff.).

${ }^{25}$ Das bürgerliche Recht und die besitzlosen Klassen (189o). 
without questioning its whither and its whence. The world had become unstable, the happy security of the time before I9I4, the naturalness in accepting situations were gone. Meaning and value of institutions had become problematic, naive positivism was no longer possible. In all fields, thought turned toward doubting, questioning, rationalizing. For the jurist, it meant a turning towards legal philosophy and sociology of law. A fundamental part of the legal structure was destroyed; it had to be rebuilt. The rest, certainly, could not remain unchanged. The German lawyer looked at other laws and began to compare. This was quite as natural as it had been heretofore not to look beyond the border. This new position opened up a wider view. Suddenly, "the law" had ceased to be Germany's own positive law, the Civil Code of 1896 , with its supplementary Acts and its mass of interpreting cases; it had become the totality of legal phenomena of all times and of all nations, "the law as a social phenomenon," as Josef Kohler had seen it. Where such an outlook is won, the object of legal science changes. It ceases to be-or to be exclusively-a "dogmatic" observation, collection, systematization, harmonization, interpretation of the positive law within which the individual jurist happens to be put. It becomes a "science about the law," an observation of the abundance of legal phenomena, of its rôle in human society, of its origins, its developments, its changes, its possibilities, its purposes, its limits. The comparative and the historical approach combine with sociology and with the science of values-political valuation under practical aspects, and philosophical valuation under the ultimate standards of justice, of ethics, of aesthetics, of religion. These are great aims, leading to new problems.

Of course, it was not at one stroke that this new attitude became common among all the German jurists, but it did determine the outlook of the leading group. Nor did the new tendencies completely supersede the old dogmatics. The services rendered to German law by the method of shaping clear-cut concepts and of placing them into a comprehensive system were too great, the German lawyers were too deeply convinced of the usefulness of seeing the law as a unity, of not letting it be split up into a vast, shapeless mass of isolated rules and cases. They were no longer satisfied, however, to pursue the old aims exclusively, and they integrated them by regarding the law from outside.

Such a viewpoint, although never completely lacking, now, for the first time, came into the foreground. In the practical realization, legal science and legal practice collaborated in the traditional German way.

A small group who had never given up their connections with foreign laws turned out to be the pioneers, the group around the Rheinische 
Zeitschrift für Zivil- ind Prozessrecht. ${ }^{26}$ Among them was Ernst Rabel, who was destined to become the creator of the new comparative law in Germany.

It was not by mere chance that this task devolved upon a Romanist. When Roman Law disappeared as actual German law, Germany's Romanists were faced with a new situation. Until then they had treated the law of the Corpus Juris as a positive law destined to regulate modern Igth century life. Now they were relegated to the rôle of pure historians, and as historians, they naturally turned to international collaboration. Moreover Romanistic science had expanded in scope. Archeological discoveries and the mass of papyri brought to light, began to reveal a new world. The laws of Ancient Greece, of the Orient, of Egypt, the entire Antiquity entered the field of research. Even Roman Law was no longer identified with the Corpus Juris, which only represented one phase of its long life. Research for "interpolations" ${ }^{27}$ in order to restore the "Classical Law," were now one of the two great tasks of Romanistic research. The other was "Legal History of Antiquity." The Corpus Juris hitherto regarded as a closed perfected system, had become the object of observation from without, and of critique, both of its text and of its rôle in history. ${ }^{28}$

On the other hand, the later history of the Roman Law inevitably led to the various laws of modern continental Europe and of Latin-America, whose concepts and systems were shaped by Roman law science and practice of the "Reception" period. For any comparison of these modern laws, as widely as they differ today, the Roman "Common Law" presented itself as the ideal basis. ${ }^{29}$

Ernst Rabel belongs to the leaders in the fields of "research for interpolations" and of papyrology, treating both within the wide scope of comparative legal history of Antiquity. From the very start, however, he did

${ }^{26}$ I909-I925. It originated from the Zeitschrift für französisches Zivilrecht (Puchelts Zeitschrift) Mannheim I870-Igo7 which was dedicated to the cultivation of French law as it was in force in the German left bank of the Rhine. By the introduction of the new Civil Code, the French Code lost its force on German soil. A small body of scholars and practitioners was not willing to give up scientific relations with it, and the Rheinische Zeitschrift founded by them included also other modern foreign laws, in connection with German law. This was its characteristic feature.

${ }_{27}$ The main part of the Corpus Juris, the Pandects, purport to be a collection of excerpts from the works of the jurists of the classical period (Ist to $2 \mathrm{~d}$ centuries A.D.). But the Compilators had not taken over these excerpts unchanged, they had adulterated them for their own purposes, they had "interpolated," under a disguised form, their own doctrines.

${ }^{28}$ Cf. V.L. Wenger, Der heutige Stand der römischen Rechtswissenschaft (I927), reprinted in Studi in onore di Bonfante (I93o), 463.

${ }^{29}$ Cf. E. Bruck, Römisches Recht und Rechtsprobleme der Gegenwart (I930); A. B. Schwartz, Pandektenwissenschaft und heutiges romanistisches Studium (I928). 
not restrict his activities to these subjects, but always combined them with his work in modern law. The fact that his career led him through three countries directed him to the comparative approach in this field. ${ }^{30}$ When he was called to the University of Munich in IgI6, he succeeded in having the state of Bavaria appropriate a modest sum for an "Institute of Comparative Law." It was an entirely new enterprise showing great foresight, all the more remarkable since it was done during the war, right in the middle of the economic blockade and intellectual isolation. The first task set to the Institute was to widen the curriculum of the University. It was planned to introduce students and young practitioners interested in comparative law to its methods and topics. But there were still other tasks set to the Institute of an immediately practical nature. It had to put foreign literature at the disposal of scholars in the fields of comparative law and of international lawyers, and it had to help them with personal advice. Furthermore-and this became particularly important in the course of years - it had to give information about foreign law to the Bavarian courts and officials in such cases where they had to apply it according to the rules of German Conflict of Laws. The courts, in their turn, were ordered to send to the Institute copies of all their decisions in cases concerning Conflict of Laws or Foreign Law, in order to give the Institute a survey of the questions with which the courts were actually occupied, so as to point out to research workers what problems demanded scientific clarification. After a short time, it became evident not only that the courts were often confronted with problems which theory had never raised but also that the number of inquiries could not be answered by the small staff of the Institute. The library, as well, although it contained adequate material for studying the most important foreign law systems, was not sufficient for practical purposes. A greater organization was necessary.

It was created within a short time, as experiences in another field demanded it. Even after the peace treaties, the struggle was not over for Germany. It was a legal struggle, to be fought before the Mixed Arbitral Tribunals instituted by the Treaty of Versailles. Each one was composed of a neutral presiding judge, a German, and an Allied associate judge. They had jurisdiction over pre-war contracts between German and Allied subjects, especially over pre-war debts, and over claims of Allied subjects against the German Reich for "exceptional war measures." ${ }^{\mathrm{r}}$ The first

30 Born in 1874 in Austria and having studied law there, in Germany, and in France, he began his legal career in Vienna. After a short while, he went, as a law teacher first to the University of Leipzig, then, in rgo6, to Basle, Switzerland, where he also acted as a judge in the Appellate Court. In Igro, he was called back to Germany, first to Kiel, then to Göttingen.

${ }^{3 x}$ Treaty of Versailles, arts. $304 \mathrm{~b}, 305$. 
decisions of these tribunals were a series of legal defeats for Germany, involving many millions of marks in the Reich's budget. The representatives on the German side talked a legal language which was not understood by the foreign judges, each of whom was accustomed only to the style of legal argumentation and technique of his own country. Furthermore the basic text, the Treaty of Versailles, was written by French and Common-Law lawyers, who had employed their own legal concepts to express the rather complicated regulations of the Treaty. The German Civil Code technique was not adequate for the mastering of such a text or for the presentation of Germany's case before these tribunals. It was imperative that each judge be addressed in his own legal language, and that the Treaty be interpreted according to French or to Common-Law methods. Thus it was necessary to find out in each specific instance whether a given rule of the Treaty had its roots in French or in CommonLaw conceptions. The German lawyers were faced with a completely novel and extremely difficult task.

It was solved in an astonishingly short time. A Scientific Department was created at the Central Office of the German Reich's Agencies for the Mixed Arbitral Tribunals. ${ }^{32}$ The German scholars of international law or similar topics were called upon to collaborate. In a new series Essays on the Peace Treaty ${ }^{33}$ many of the new problems facing Germany were discussed by eminent lawyers.

These efforts had practical results. The German defense learned to talk to the foreign judges in their own respective legal languages, they learned the technique of foreign procedure and to approach the Treaty of Versailles with an appropriate method of interpretation. ${ }^{34}$

A second big task with which post-war Germany was faced, was the reconstruction of German foreign trade, almost completely destroyed by the war. The German exporters and importers, the banks, German shipping, insurance companies, all needed legal advice, which was difficult to obtain from foreign lawyers. It had to be furnished inside of Germany. With the collaboration of Joseph Partsch, Heinrich Titze, and Martin

${ }^{32}$ It was significant that here, too, a Romanist, Joseph Partsch (he died in 1925) was selected director, who like Rabel had worked in the fields of legal history of Antiquity, interpolationresearch and papyrology. He also had taught law in Switzerland, at Geneva, where he had become familiar with Swiss and French law and had lived in the atmosphere of French civilization.

33 Abhandlungen zum Friedensvertrag (edited by Joseph Partsch and Heinrich Triepel).

34 The difference between the first and the later years will be revealed by a glance over the volumes of the Recueil des Décisions des Tribunaux Arbitraux Mixtes. With every year the German defeats became less frequent; another reason is, of course, the changed political atmosphere, 
Wolff, professors at the University of Berlin, the "Reich Association of German Industry" 35 created a "Foreign Law Information Bureau" 36 which had to answer inquiries about foreign law and to publish current reports on important legal events abroad in the new periodical Foreign Law. ${ }^{37}$ A similar, smaller service was founded by the "Hansa-League," ${ }^{8}$ a leading organization of German Commerce, which also edited a periodical Legislation and Legal Practice Abroad. ${ }^{39}$

Legal doctrine and legal practice having been confronted with new problems, a series of new organizations had been created, but each one soon proved to be too small. Moreover, there were new scientific needs in the fields of Constitutional and of International Law. The Reich had established the Weimar Constitution of August II, Igrg, the "most democratic constitution of the world," in many respects imitating the great Western democracies, especially in its Bill of Rights and Duties. ${ }^{40}$ Interpretation and application of this constitution could not ignore constitutional doctrine of the West. Furthermore, as a result of the debacle of the old Reich, critical observation of current constitutional doctrines was unavoidable. In International Law, Germany was faced with a large task of reconstruction. International relations interrupted by the war were to be resumed. The new problems of reparations, disarmament, minorities, mandates, all regarded as vital in Germany, had to be dealt with. The new Permanent Court of International Justice was to be taken into account..$^{4 I}$ International Law is based upon the common legal conscience of all civilized nations. The Permanent Court of International Justice itself is directed by its own statute to decide according to "The general principles of law recognized by civilized nations" (art. 38), which are the expression of this common legal conscience. They cannot be ascertained other than by Comparative Law. The leaders of the science of International Law were called upon to take an active part in the various cases before the International Court. The science of International Law received a mighty impetus by this contact with practical problems. It was intensified, and turned to a positivistic-inductive method, based on state practice, international court decisions, and Comparative Law. ${ }^{42}$

${ }^{35}$ Reichsverband der Deutschen Industrie.

${ }^{36}$ Auskunftsstelle für ausländisches Recht. 37 Auslandsrecht (r920-1926).

${ }^{8}$ Hansabund.

39 Gesetzgebung und Rechtspraxis des Auslands (1925-193r).

${ }^{40}$ Arts. rog-r65.

4x Until June I5th, I933, the Court delivered judgments or opinions in thirty-nine cases; Germany or Danzig were parties in fifteen of these cases.

${ }_{42}$ Cf. Rabel, Rechtsvergleichung und Internationale Rechtsprechung, in Zeitschrift für ausländisches und internationales Privatrecht I. 5; Victor Bruns, Völkerrecht als Rechtsord- 
Out of all these necessities and tendencies, a plan for a new comprehensive organization was originated, of a large scientific institute with a big international and foreign law library and an ample staff of trained specialists, designed to deal with scientific as well as with practical problems. It was carried out under the auspices of the "Kaiser Wilhelm Association for the Advancement of Science," 43 which created two institutes for research in law, an Institute of Foreign and International Private Law and an Institute of Foreign Public Law and International Law. The two Institutes were intended to collaborate closely. The not inconsiderable funds were furnished by the Reich and, to a smaller extent by German industry and banks. The "Scientific Department" of the Reich's Defence Agency and the greater part of the Information Bureau of the Reich's Industry Association were merged with the Institutes. Ernst Rabel became director of the Private Law Institute; the Public Law Institute was put under the direction of Victor Bruns. In spring, I926, the new Institutes began their activities with a combined staff of about twenty-five research workers specializing either in particular legal systems or in particular problems. The necessary library was soon created, ${ }^{44}$ also an archive of living law documents.

A large volume of manifold tasks is set to the Institutes. They have to prepare comparative law material for the central departments of the Reich and to advise them in legislative matters; 45 they have to suggest

nung, in Zeitschrift für ausländisches öffentliches Recht und Völkerrecht I. I, III. 445; cf. also the new comprehensive collection of International Law material from decisions of national courts in Fontes Juris Gentium, edited by the Institute für ausländisches öffentliches Recht und Völkerrecht.

${ }_{43}$ (Kaiser Wilhelm Gesellschaft zur Förderung der Wissenschaften.) This organization was founded in IgIr, on the suggestion of Adolph Harnack, to establish research institutes for eminent scientists as e.g. Einstein, Haber, Willsteutter, Eugen Fischer. The first institutes were dedicated to pure or to applied natural science.

44 Embracing more than $r 80,000$ volumes it is now the largest International Law library in Europe. It contains not only the statutes and law treatises of almost all states but also the reports, the periodicals and the leading monographs. The department of American law literature e.g. contains besides the usual textbooks of a general nature and those texts dealing with the laws of the various states, the National Reporter System and the older reports down to its beginning, the various sets of Annotated Reports, the United States Supreme Court and other Federal reports, including the smaller Federal tribunals and commissions, the usual cyclopaedias and search-books, for each state the latest statute law compilation with continuing session laws, and finally an almost complete set of law periodicals.

$45 \mathrm{Cf}$. Hallstein, Die Aktienrechte der Gegenwart (Modern Corporation Laws) (edited r93I by the Institute for Foreign and Private International Law); Das Recht des Ausnahmezustandes im Ausland (rg28), and the series Foreign Press Laws (Die Pressgesetze des Erdballs) (edited by Viktor Bruns and Häntzschel [Institute of Foreign Public Law and International Law] I928 ff.). 
recommendations to the central organizations of German industry and commerce in important problems of law reform ${ }^{46}$ and of foreign trade; they have to co-operate in international law unification ${ }^{47}$ with corresponding organizations abroad; they have to furnish information on foreign law in cases pending before German courts and in connection with practical questions of international legal relations; ${ }^{48}$ they have to report currently, as far as possible in collaboration with foreign scholars, ${ }^{49}$ on the development of legislation, case law, and legal doctrine of foreign countries; they have to furnish bibliographical data and to put the necessary material at the disposal of German and foreign scholars. ${ }^{\circ 0}$ Each Institute publishes a periodical ${ }^{5 x}$ and a series of dissertation $\mathrm{s}^{52}$ in its respective field. Furthermore-and this is the most important task-they are intended to do their own research work, the individual members as well as the Institutes as such. The specialists of the different legal systems are intended to collaborate in collective team-work with the aim not to describe the various single systems but to work out the comparative aspects.

The two Berlin Institutes are not engaged in teaching, although the directors and some of the members of their staffs are also members of the Law Faculty of the University of Berlin. But the Institutes form the nucleus of a group of smaller university institutes and seminars, essentially designed for teaching purposes..$^{53}$

${ }^{6} \mathrm{Cf}$. e.g. the survey in Foreign Laws on Bank Deposits, published in 4 Zeitschrift für ausländisches und internationales Privatrecht, 445.

47 Until Germany's declaration of withdrawal from the League of Nations, the Private Law Institute worked in close cooperation with the League's Institute for the Unification of Private Law in Rome, for which it prepared, among other things, a comparative survey on the Law of the Sale of Goods, published in a tentative form in r929. Rapport sur le droit compare en matière de vente, Société des Nations. U.D.P. Etudes IV. S.d.N. I929, 1. I), I929.

${ }_{48}^{8} \mathrm{It}$ is necessary for the domestic judge and the domestic lawyer to learn the foreign law in terms he is able to understand. Where foreign law is proved by the opinions of foreign lawyers, there is always the danger of mutual misunderstandings.

49 But not exclusively by them, because they do not know which problems are of special interest to the domestic readers or for comparative purposes, and because they are very seldom able to expound their own law to foreign-trained minds.

${ }^{\text {so }} \mathrm{Cf}$. Kaden, Bibliographie der rechtsvergleichenden Literatur 1870-1928. This was published in I930 by the Private Law Institute.

sI Zeitschrift für ausländisches und internationales Privatrecht (Review of Foreign and International Private Law) (I926 ff.); Zeitschrift für ausländisches öffentliches Recht und Völkerrecht (Review of Foreign Public Law and International Law) (rg29 ff.).

53 Abhandlungen zum ausländischen und internationalen Privatrecht; Abhandlungen zum ausländischen öffentlichen Recht und Völkerrecht.

53 Munich, now directed by Erwin Riezler, until recently together with Karl Neumeyer; Frankfurt, directed until I932 by Hans Lewald, now Professor in Berlin and member of the Berlin Institute; Hamburg: Institute of Foreign Law, International Private law and Interna- 
III

Previous attempts in Comparative Law, both in Germany and abroad, had set their aims too high and could therefore exert only little influence. The new German Comparative Law confines itself to aims that can be attained. Rabel has framed a program of its methods. The last goal, to be sure, remains a high one:

"The Law of the entire world must be the object of our observation, past and present, the connection between law and soil, climate, race, with the historical fates of nations - war, revolution, creation of states, subjugation - with religious and ethical preconceptions; ambitions and creative power of individuals; the needs of production and consumption; the interests of groups, parties, and classes. Intellectual tendencies of every kind are at work, as e. g. feudalism, liberalism, and socialism, each of which creates different laws. Logical consistency ways of legal thought once entered upon, and last but not least, the search for the ideal state, the ideal law, all these are interwoven in the social-economic structure. The law of every civilized nation is trembling and glimmering in a thousand colours in sun and wind. All these vibrating bodies together form a picture not yet conceived by anybody." 34

This is an overwhelming plan, but it remains a last aim, perhaps unattainable. It remains in the background as an ideal. But the concrete work is more modest, it must start with the small detail, it must be carried out with the same minuteness, the same accuracy as any work in one's own law, as any other research in history or in social science.

Rabel distinguishes different parts of Comparative Law: Ethnological Jurisprudence, investigating the human foundations and the beginnings of legal development by observing the laws of primitive nations and awakening civilizations. Historical Comparison, starting with the empirical observation that identical or similar situations usually produce

tional Civil Procedure law specializing in Anglo-American Law and until recently directed by Albrecht Mendelssohn Bartholdy and Margarethe Schoch; also the Institute of Nordic law, directed by Haff; Cologne, where until recently Hans Goldschmidt edited a series of remarkable essays on English law; Königsberg, Institute of Air Law (Otto Schreiber, deceased in I929, and now Hans Oppokofer); Heidelberg, Institute of Foreign Law, where Karl Neubecker and Karl Heinscheimer, two pioneers of German Comparative Law, were active, and which is now directed by Max Gutzwiller; Breslau, Law Department of the Eastern Europe Institute (until recently under Richard Schott and Friedrich Schöndorf) especially interested in the laws of the slavonic nations and of the Soviet Union. It publishes the periodical, Zeitschrift für Ostrecht (I927-r934) (continuing the Zeitschrift für Osteuropäisches Recht [I925I927]). Also the large Institute of World Commerce and Shipping at Kiel, directed until recently by Bernhard Harms and publishing the Weltwirtschaftsarchiv (rgr3 ff.), works on problems of law. An Institute for Foreign and Economic Law, directed by Ernst Heymann, and affiliated with the University of Berlin arranges lectures by German and Foreign experts in Berlin.

54 Rabel, Aufgabe und Notwendigkeit der Rechtsvergleichung, in $x_{3}$ Rheinische Zeitschrift für Zivil- und Prozessrecht 283; also published separately in Münchner Juristische Vorträge, (H. I. 1925). 
identical or similar legal phenomena among various nations, it attempts to clear up dark spots in the tradition of historical laws by looking at other nations living under similar historical circumstances. Carefully applied this method is today commonly used in historical research.

The third branch of Comparative Law is, what Rabel calls SystematicDogmatic Comparative Law, the comparison of the developed legal systems of today. His postulate is: "Comparative Law not Comparative Legislation." "It is insufficient to compare code sections. We must consider the practice of legal transactions, especially type-forms, and the practice of the courts. A code without its accompanying cases is but a skeleton without muscles. Prevailing doctrines are the nerves. . . . . Not less indispensable for our knowledge are the historical origins and the natal hour of a Law." In short, we must regard the entire law of a country as it appears from statutory texts, the practice of the courts and of business, its historical origin, its literature and doctrine; and beyond this whole "law in discourse" the "law in action," its actual application, the methods of judicial reasoning, of legal thought and of law teaching, organization and position of the legal profession, their ethical standards and their social reputation, the attitude of the public toward the law and its functionaries, satisfaction of critique, reform tendencies, the ways of legislation, and the place of the law in the social life of the nation. The spirit of each legal system must be made living. This is the first postulate.

The second: we must start with the small concrete detail, but we must never look at it as an isolated fact; we must always see it as a part of an entirety. The isolated rule is meaningless, its significance does not appear except in connection with other rules. The rule of French intestate succession law denying in the majority of cases to the surviving spouse a free share in the estate of the predeceased, ${ }^{55}$ appears in another light if regarded together with the rules of French law as to matrimonial property, regularly establishing a community of all chattels and of gains, ${ }^{56}$ and giving the surviving spouse one half of the community property. ${ }^{57} \mathrm{~A}$ comparison of German unjust enrichment ${ }^{58}$ with Anglo-American quasicontracts would be insufficient. We must also take into account the constructive trust, whose effects are, in their turn, achieved in the law of France, by the theorie de la cause. ${ }^{59}$ An American observer comparing vicarious liability in Anglo-American and in German law would be misled, if he looked only to the sections of the German code which expressly deal

ss Code Civil, art. 767 .

"Code Civil, art. I399 ff.

57 Code Civil, art. $1453, \mathrm{r}_{46} 6 \mathrm{ff}$.

$5^{8}$ German Civil Code, \$§ 812-822.

59 Cf. my review of Lepaulle, Traité théorique et pratique des Trusts, in 43 Yale L. J. I049 (I934). 
with torts, and where the master is under no liability, if he proves the absence of any negligence of his own in selecting and supervising his servant. $^{60}$ The observer must also take into account the Code sections on contractual responsibility which do not give the master such a possibility of exoneration, and which have been extended by the Courts to many cases which neither in the United States nor in France would be regarded as contract cases. We understand the different attitude of American and German courts to commercial customs, ${ }^{6 \mathrm{x}}$ if we consider the differences in proving such customs in procedure: partisan expert witnesses testifying before a jury on the one side, official experts appointed by and testifying before the judge on the other side. ${ }^{62}$

These few examples may indicate the essential point: the function of a legal institution not its conceptual shape; the purposes it serves not its formal place in the legal system. How are the problems set by life, how are the actual conflicts of social interests solved by the legal order? Such a comparison very often shows that different legal systems may use different technical means for the same purpose. The Anglo-American institution of trust does not exist as such in the continental laws. But its purposes may be achieved to a considerable extent by using other institutions: fiducia and authorization, institution of a reversionary heir and usufruct, foundation, purpose-gift, gift under a charge and others. ${ }^{63}$ There remain some purposes of the trust, however, which cannot be achieved in German or in French law be cause the ideals of legal politics are different. English or American liberalism leaves more room to private autonomy in legal transactions than the more rigid laws of the European continent. There, the state exerts a closer control over private transactions for the sake of a greater perspicuity of the legal system, and to make property relations more apparent for the protection of third parties, especially of creditors and of prospective creditors. It is only when we observe a legal institution with regard to its functions and as a part of its entire legal system, and when we have found which institutions of another legal

60 German Civil Code, $\S 831$.

6r Commercial Code $\S 346$ : "Among merchants, the usages and customs prevailing in trade are to be taken into account with respect to the meaning of acts and omissions." As to the United States cf. e.g. Barnard v. Kellogg, 77 U.S. 383 ; A. T. Wright, Opposition of the Law to Business Usages, 26 Col. L. Rev. 9 I7 (Ig26).

6 Cf. also the interesting Italian experiment of official collections of the commercial customs of each province (Raccolte ufficiali degli usi di commercio), instituted by the Provincial Economic Councils, which may be used in court as conclusive evidence (Corte di Cassazione del Regno, April 27, I93I, Rivista di Diritto Commerciale, I93I, p. Ig).

${ }_{6}$ Cf. Siebert, Das rechtsgeschäftliche Treuhandverhältnis (Marburg in Hessen I932). 
system can be used for the same or for kindred purposes, that we may see whether, and in what respects, the two systems really differ. It is striking to observe how comparatively seldom such real differences exist. The unity of our occidental civilization becomes apparent under all the dissimilarities on the surface. Where the systems do not coincide, there we are faced with the second task of explaining the reasons and of demonstrating the consequences.

Such a functional approach opens our eyes to an understanding of the rôle of legal concepts and of technique in law. Each legal system uses certain fundamental concepts in order to express its rules. In different legal systems, these concepts often differ, but comparative observation reveals how little such concepts constitute ends in themselves, that they are nothing but blocks with which to build structures. On the other hand, we find, of course, how the shape of the blocks influences the structure, how it is responsible for its style, and so we find how sometimes differences in the effects of legal rules can be caused by differences of the legal concepts used.

But not always can comparative research start with the function of a legal institution. In observing our domestic laws we frequently overlook it. We often take the traditional institutions for granted without thinking much about their raisons d'être. Comparison with other laws leads to closer consideration, reveals the functions, and thus opens the way to creative criticism. Legal institutions of whose functions we are conscious no longer have the tendency to go their own way, which may not always be desirable. For instance some developments of the concept of consideration in England have prevented the recognition of the contract for the benefit of a third person up to the present day. ${ }^{64}$ Conceptual thinking has for a long time kept alive the idea that a buyer's remedies for defects in quality were destroyed by his acceptance of the goods..$^{65}$ The English rule in Chandler $v$. Webster, ${ }^{66}$ prevented for pure conceptual reasons an action for the restitution of money paid in fulfilment of a contract, in which the other party's performance turns out to become impossible. Instances of such a kind may be found in every law. Comparative observation makes us detect them in our own law. It shows us where a necessary develop-

${ }^{64}$ Dunlop Tyre Co. v. Selfridge, [19r5] A.C. 847 .

os The sale is completed by the acceptance of the goods. How is it possible that there remains a claim for damages? One had to seek refuge in the artificial construction of a collateral agreement. Cf., e.g., Gaylord Mfg. Co. v. Sarah O. Allen, 53 N.Y. 5I5 (1873); Scranton v. Mechanics' Trading Co., 37 Conn. 130 ( 1870 ).

${ }^{66}$ [I904] I K.B. 493. 
ment is prevented by such conceptual considerations and points to an eventual way out.

This functional approach, whose first conscious exponent was probably Eduard Lambert, the founder of modern French comparative law, ${ }^{67}$ is the method of the new German comparatists. It finds a particularly important application in legislative reform, where it shows how a given problem demanding a reform at home is solved abroad. In our modern world, the problems demanding regulation by law are alike, often identical in many countries, especially in countries of a similar economic structure. Comparative law will show us the variety of means which may be and have been used for the same purposes, thus enlarging our "stock of solutions." ${ }^{\prime 68}$ It is often astonishing to see how problems suddenly arising in a country and regarded there as absolutely new, have already puzzled other countries, in which various solutions have been thoroughly tested out-they may have succeeded or failed. ${ }^{69}$ In an additional branch of comparative law, the results of its three positivistic branches-ethnological jurisprudence, historic comparison, and dogmatic-systematic, or better, functional comparative law-are brought together with valuating criticism, with legal sociology, and with legal politics. It extends into legal philosophy and it aims at a comprehensive view of the law, of its growth, its forms, its purposes and its effects.

\section{IV}

In present day German comparative law, particular stress is laid upon the functional comparison of modern laws. The aim is to understand the various systems prevailing throughout our modern world, and, as its main task, to utilize the results for development of German law.

German legal methods underwent a thorough change during the last two decades. Observation of the law from within has been integrated by observation from without in two respects. After long methodological discussions, the old conceptual jurisprudence was replaced by new meth-

${ }^{67} \mathrm{La}$ fonction de droit civil comparé (Etudes de droit commun législatif) (rg03).

68 Zitelmann.

69 After the crashes of 1873 and 1890 , Germany was faced with problems of Stock Exchange and Corporation Law reform similar to those now urgent in the United States. The investigations and reports of that time (Materialien der Börsenenquétekommission 1892 , 93, printed in the Reichsdruckerei. 4 vols.; Max Weber, Die Ergebnisse der deutschen Börsenenquête, in Zeitschrift für das gesamte Handelsrecht, vols. 43-45)-and the experiences Germany made with the ensuing legislation (Stock Exchange Act of June 22d, I896, reformed by Act of May 8th, 1908; changes in the corporation law by the Act of July 18 th, 1884 ; as to recent reforms in Corporation Law cf. the Act of September Igth, r93r, and the so-called 2d Draft on Corporation Law, published by the Reich's Ministry of Justice of $x_{93}$ I) could furnish interesting materials for other countries. 
ods. ${ }^{70}$ Discussions similar to those now going on here in the United States between traditionalists, legal sociologists and realists took place in Germany. Our "realists," the free-law and sociological-school (H. Ehrlich, ${ }^{7 x}$ Kantorowicz, ${ }^{72}$ Ernst Fuchs, ${ }^{73}$ Stampe, ${ }^{74}$ Wüstendörfer ${ }^{75}$ ), legal facts research (Rechtstatsachenforschung; Arthur Nussbaum ${ }^{76}$ ), the so-called economic law movement (Wirtschaftsrecht, ${ }^{77}$ Hedemann, ${ }^{78}$ Heymann, ${ }^{79}$ Geiler $^{80}$ and others), teleological jurisprudence (Thering ${ }^{8 \mathrm{x}}$ ), especially the so-called Tübingen-School of "Interest-Jurisprudence" (Interessenjurisprudenz; v. Rümelin, ${ }^{82}$ Heck, $^{8_{3}}$ Müller-Erzbach ${ }^{84}$ and many others ${ }^{85}$ ),

${ }^{30} \mathrm{Cf}$. the vivid presentation by M. Rümelin, Erlebte Wandlungen in Wissenschaft und Lehre (1930); in addition: Gutzwiller, Gegenwart und Zukunft der Privatrechtswissenschaft (I927). Also instructive, although only regarding Public Law and Criminal Law: E. Schwinge, Der Methoden-Streit in der heutigen Rechtswissenschaft (r930). The changes in the practice of the courts are best represented by the monumental symposium dedicated by the German law faculties to the Reichsgericht (Die Reichsgerichtspraxis im deutschen Rechtsleben, Festgabe der juristischen Fakultaten zum 50 jährigen Bestehen des Reichsgerichts) (6 vols. r929); therein esp. W. Sauer, Die grundsätzliche Bedeutung der höchstrichterlichen Rechtssprechung für Wissenschaft and Praxis. I. I22. R. Müller-Erzbach, Reichsgericht und Interessenjurisprudenz. II. I6x. Rich. Schmidt, Das Reichsgericht und die deutsche Rechtswissenschaft. II. 293. A. Mendelssohn Bartholdy, Imperium des Richters. VI. I. Cf. also Hedemann. Reichsgericht und Wirtschaftsrecht (rg29).

7T Freie Rechtsfindung (I903); Grundlegung der Soziologie des Rechts (IgI3).

7 Cf. above, also Rechtswissenschaft und Soziologie (IgrI).

73 Schreibjustiz und Richterkönigtum (I907); Gemeinschädlichkeit der konstruktiven Jurisprudenz (IgOg); Juristischer Kulturkampf (rgr2); Was will die Freirechtsschule? (r929).

74 Ueber Rechts- und Begriffsbildung (Igo7); Die Freirechtsbewegung (Igrr).

${ }_{75}$ Die deutsche Rechtssprechung am Wendepunkt (I9I3); also Archiv für die zivilistische Praxis xro. 2rg.

${ }^{76}$ Rechtstatsachenforschung (I9I4).

77 Cf. Klausing in Beitrag zum Wirtschaftsrecht (r93 $x$ ), $\mathrm{I}$.

${ }^{28}$ Director of the Institute für Wirtschaftsrecht in the University of Jena and editor of the Mitteilungen des Jenaer Instituts für Wirtschaftsrecht.

79 Editor of Arbeiten zum Handels, Gewerbe u. Landwirtschaftsrecht.

80 68 Die wirtschaftsrechtliche Methode im Gesellschaftsrecht, in Gruchot's Beiträgen (rg27), 593 .

${ }^{8 x}$ Cf. H. Lange, Die Wandlungen Therings in seiner Auffassung vom Recht (1927).

8a Die Rechtssicherheit (I924); Das Problem der Gerechtigkeit (I920); Die Billigkeit im Recht (I92I); Rechtsgefühl u. Rechtsbewustsein (r925).

${ }_{83}$ Das Problem der Rechtsgewinnung (IgI2); Gesetzesauslegung und Interessenjurisprudenz (rgI4); Begriffsbildung und Interessenjurisprudenz (I932); Praktische Anwendungen der Methode in Grundriss des Schuldrechts (I929) (esp. pp. II ff. and $47 \mathrm{I}$ ff.) and Grundriss des Sachenrecht (r930).

${ }_{4}$ Wohin führt die Interessenjurisprudenz? (I932); Die Relativität der Begriffe und ihre Begrenzung durch den Zweck des Gesetzes (rgr3).

ss Cf. esp. Stoll, Begriff und Konstruktion in der Lehre der Interessenjurisprudenz in der Festgabe für Heck, Rümelin, A. B. Schmidt (I93I), 60 ff.; an interesting critique of the "Interest-jurisprudence" is given by Oertmann, Begriff und Interesse in der Rechtswissenschaft (193x); answered by Heck in Juristische Wochenschrift (1933), 29. 
have widened the jurist's task. The solutions of the problems presented by life itself cannot be found in isolated rules of law, but we must look at the conflicting social interests which are to be regulated. American realists, however, differ in some respects. ${ }^{86}$ German legal scholars have always regarded it as their task to find legal solutions for the conflicts of social life, but they have never confined themselves to an art of prophesying what judges are likely to do ${ }^{87}$ Of course, modern German jurisprudence does not neglect the judicial process, it does not exclude the law in action from its observation. On the contrary, it regards it as an indispensable subject for the jurist's studies, but not as the only one. The German jurists do not deny that the law is a body of rules-whosoever may be their addressee, the public or the law-applying officials. They regarded and still regard it as their task to expound and to develop these rules, to propose solutions for cases not provided for by the codes, the statutes or the existing case law. They are of the opinion that the law must always strive for generalizing norms, not merely for just decisions of isolated cases. The new case, never conceived before, is for the jurist nothing but an example of a general set of similar cases. It is recognized

${ }^{86}$ For a critique of American realism cf. Kantorowicz, Some Rationalism about Realism, 43 Yale L.J. I240 (1934); Max Ascoli, Realism and the Constitution, I Social Research I69 (r934); and see Rudolf Littauer's review of Llewellyn's Präjudizienrecht und Rechtsprechung in Amerika, I Social Research 528 (I934).

${ }_{77}$ There is a characteristic difference between German (or European continental) and English-American legal science. The continental legal scholar reflects in advance on new problems which were never before decided by the Codes or the courts. He leads the practice. The Anglo-American text-book writer and teacher of law is inclined to confine himself to expounding what the courts did in the past. When legal science developed in England and in the United States during the second half of the Igth century, it was first legal history (Pollock, Maitland, Maine, Langdell, Ames). The 2oth century brought the observation of the "Iaw in action" of the observer's own period. Comparative law may venture an explanation for this different attitude, based on differences in the historical development. Whereas, in England, law was, until recently, generally taught by practitioners outside of the universities, it was taught on the continent by university professors. Whereas in England the judges were the protagonists of the individual's liberties against the absolutism of the Crown, continental judges were too dependent upon the princes and rulers to assume such a rôle. University professors were as members of self-governing corporations comparatively less dependent. Thus they were able to keep at least private law to a certain degree free from interferences by the rulers. These facts resulted in making them the leaders of the profession. Until the nineteenth century courts were accustomed to ask law faculties for advice and to send to them, in difficult cases, the files so that they finally should decide questions of law (so called "Aktenversendung"). Professors not only taught law but also wrote the legal treatises and essays. As a result, they became accustomed to the idea that they had to guide the courts.

In the United States, the rise of the university law school and the university law review will probably lead to the same direction. There are already significant symptoms (cf. Judge Cardozo's preface to Selected Essays in the Law of Contracts [193I]), although the case method may have somewhat retarded this development. See Hutchins, The Autobiography of an ExLaw Student, I Univ. Chi. L. Rev. 5 II (I934). 
that the formulated rules only cover a small set of type problems, that the rules for new types of cases are still to be developed. But it is also recognized that this must be done "within the spirit of the legal order," that the politics and value judgments, as they are laid down in the already formulated rules are to be adhered to. Thus, two sets of facts are to be taken into account: the life situations to be regulated, and the politics and evaluations guiding the regulating activities. To know them both, the jurist must put himself outside of the body of the existing rules. He must closely observe the facts of life, economics and other social phenomena. $\mathrm{He}$ must know the political tendencies of the community. The creative lawyer must be much more than a repository of rules. Such an observation of the functions of the law and of the social conflicts to be regulated would be incomplete if it stopped at political boundaries. A functional approach, a sociological as well as a realistic jurisprudence are necessarily pressing towards comparative law, without which they remain fragmentary. ${ }^{88}$

In doctrine and development of German law, it has become quite natural to consider foreign comparative material. ${ }^{89}$ The difference from the preceding period will be revealed by a superficial glance over recent law treatises, especially over the recent editions of the standard treatise on Private Law, Enneccerus-Kipp-Wolff.90 For the already considerable number of young law teachers who have gone through the new Comparative Law Institutes, it is quite natural to illustrate the institutions of German law by pointing to foreign law phenomena, and thus to make their own law more plastic, and to open the student's eyes to the functions of the legal institutions. Their method finds imitation even among the older generation. The institutions of German law become more under-

${ }^{88}$ The realistic approach will find its own confirmation by observing that the same tendencies are successfully at work abroad. American sociological jurisprudence (Roscoe Pound) and American realism have furnished to the new German jurisprudence many a valuable suggestion. For a German exposition cf. Angèle Auburtin, Amerikanische Rechtsauffassungen und die neueren amerikanischen Theorien der Rechtssoziologie und des Rechtsrealismus, in Zeitschrift für ausländisches öffentliches Recht und Völkerrecht (3, 529).

89 Even the candidates for the doctor's degree feel obligated to refer in their dissertations to foreign comparative material, although sometimes somewhat superficially. But such exaggerations show at least that already the average lawyer is aware of the fact that it is insufficient to approach legal problems entirely from inside of the German law, and that he thinks he is expected to look beyond.

Most recently, however, some lawyers regard it as necessary to excuse themselves and to state that they do not attempt to "degermanize" the German law, when they refer to foreign legal ideas.

90 Introduction and General Part ( 13 th ed. by H. C. Nipperdey I93 1 ); Obligations ( 12 th ed. by H. Lehmann 1932); Property (9th ed. by M. Wolff I932); Familial Law (7th ed. by M. Wolff and Th. Kipp r93I); Inheritance Law (8th ed. by Th. Kipp I930). 
standable to the student if they are contrasted with those of foreign countries, if for instance the German system of marriage and divorce is presented together with the foreign system; if the various systems of land registration are explained and if it is shown how other legal systems attempt to solve the problems of land transactions without registration; if it is pointed out how the German law of torts stands in the middle between the French system of broad general regulation and the Anglo-American system of a casuistic catalogue of various torts. ${ }^{9 x}$ It seems self-evident to a German student that every system of contractual obligation must be based upon the claim for specific performance. It stimulates his understanding if he is told that other systems give such a claim only in exceptional cases and regularly only claims for damages for breach of contract. According to whether a system takes the former or the latter view, the doctrines of impossibility of performance, of mutual interdependence of performance and counter-performance, of warranty, of breach of a time term (the continental mora-doctrine) are different. ${ }^{92}$ The complicated German regulation of an heir's liability for the deceased's debts ${ }^{93}$ becomes conspicuous when compared with the different systems of Anglo-American law, where the debts are paid by the personal representative before the estate is distributed, and with that of Austrian law, where the estate is taken over by the state.

Foreign legal thought is utilized for the better development of German legal institutions. An abundance of new ideas are pouring in, old ideas are clarified, sometimes corroborated, other times confuted. Here are a few examples: The German discussions, what consequences of an injurious act are too remote to be compensated, find a parallel in the English and American discussions of proximate cause. The German theory of "adequate causal relation" has its counterpart in the Anglo-American foreseeability doctrine, the English and American criticisms of which ${ }^{94}$ motivate, in their turn, a revision of the German theory, together with a new doctrine developed in Austria (Ehrenzweig, Wilburg); it will probably lead to a new device severing the reparable from the irreparable damage accord-

${ }^{91}$ Cf. French Civil Code Arts. I382-1386 with $\$ \$ 823-853$ of the German Code (with its supplementary Acts), and the Restatement on Torts.

${ }_{92}$ Cf. Rheinstein, Die Struktur des vertraglichen Schuldverhaltnisses (Berlin, I932); Institut für ausländisches und internationales Privatrecht. Rapport sur le droit comparé en matière de vente (cf. supra note 47).

93 German Civil Code $\$ \S 1967-2017,2058-2063$.

94 Beven, Negligence (Ist ed. I889) 75; Bohlen, The Probable v. the Natural Consequence as the Test of Liability in Negligence, $40 \mathrm{Am}$. I. Reg. (N.S.) 79 (Igor); Jeremiah Smith, Legal Cause in Actions of Tort 25 Harv. L. Rev. Io3 (Igrr); J. H. Beale, the Proximate Consequences of an Act, 33 Harv. L. Rev. 633 (I920); cf. also the Polemis Case, [I92I] 3 K.B. 560 and the ensuing discussions. 
ing to the extent of the zone of protection erected by the rule which establishes the obligation in damages. An investigation of the AngloAmerican doctrine of negligence ${ }^{95}$ shows new solutions for the problem, so much discussed in Germany, how a person who has, by contract, undertaken to do something can be held responsible towards third persons, who are not parties to the contract and who have suffered damage by a misfeasance or nonfeasance as to the contractual obligation..$^{96}$ If, besides, we take into account the French action directe, we obtain a view of the whole complex of problems, how a contract entered into by two parties may be brought into legal connection with the relations in which the contracting parties stand with other persons. ${ }^{97}$ When we observe under a comparative aspect, how the German Reichsgericht attempts to secure the general creditors of a merchant who has turned over his entire assets, as collateral, to the bank financing him, ${ }^{98}$ we recognize this problem as a part of the general problem, how the law ought to approach the modern division between trade and finance. We can clearly recognize the interests at stake, and we can mould our rules of law accordingly.

Thus a scientific treatment of any important problem of German law is hardly conceivable any longer without making use of foreign material.99

The literature dealing with German law in the comparative method is accompanied by many essays and treatises devoted to foreign laws, as, for instance, besides many monographs, ${ }^{\text {xoo }}$ a collection of translated ${ }^{\mathrm{xor}}$ and annotated foreign codes and laws, ${ }^{\text {xo2 }}$ Nussbaum's International Yearbook

${ }_{95}$ Cf. Kessler, Die Fahrlassigkeit im anglo-amerikanischen Deliktsrecht. Beiträge zum ausländischen u. internationalen Privatrecht $\left(x_{932}\right)$, n. 6.

${ }_{96}^{6}$ The problem of MacPherson v. Buick Motor Co., 217 N.Y. 383, IxI N.E. I050 (I9I6).

${ }^{97}$ A study on this subject, prepared in the Private Law Institute, will be published shortly.

${ }_{98}$ Cf. especially the decision of the German Reichsgericht of April gth, I932, RGZ. r36, 247.

99 Cf. e.g. Nussbaum, Das Geld (The Money) (I925); Siebert, Das rechtsgeschaftliche Treuhandverhältnis (Fiduciary relations created by legal transactions) (I933); the clarifying treatment of the long debated questions of compensatio lucri cum damno by Wilburg (in Jahrbücher für Dogmatik (r933) 56; Ernst Cohn, Das rechtsgeschaftliche Handeln für denjenigen, den es angeht (Undisclosed principal) (I93I); Rühl, Eigentumsvorbehalt und Abzahlungsgeschäft (Bills of Sale) (I930); Grossmann-Dörth, Das Recht des Ueberseekaufes (Maritime Sales Transactions) (I930); and others. Cf. Wahl, Verhagsansprüche Dritter im französischen Recht (Berlin, I935).

${ }^{200}$ Which show a predilection for Anglo-American law, which is particularly instructive just because it is so different.

ror Every good legal translation is in itself comparative law!

${ }^{102}$ Die Zivilgesetze der Gegenwart, first edited by the late Karl Heinsheimer, and now by the Institute of Foreign and International Private Law; hitherto published: vol. I: Frankreich, Code Civil (I932), vol II: Das Zivilrecht Englands in Einzeldarstellungen. Ist part (I93I); vol. III: Brasilien. Codigo civil. I928; vol. VI: Sowjet-Union (I927); vol. X: Nordische Länder (1933). 


\section{of Commercial Arbitration, ${ }^{\mathrm{x} 3}$ Magnus' Tables on Foreign Law, ${ }^{\text {x04 Leske- }}$} Löwenfeld's Pursuit of Law in International Relations ${ }^{\text {T05 }}$ and especially the great Comparative Law Dictionary. ${ }^{\text {Io6 }}$ Also several numbers of the Juristische Wochenschrift, Germany's leading general legal periodical, were dedicated to foreign and international law topics. Other works dealing with problems de lege ferenda, are making use of foreign material for current problems of German law reform and legislation, as for instance in the fields of corporation law, ${ }^{\text {107 }}$ civil procedure, ${ }^{108}$ of cartels and monopo-

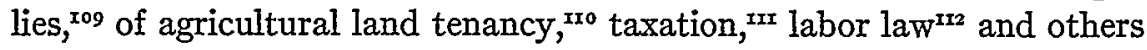

${ }^{103}$ Internationales Jahrbuch für Schiedsgerichtswesen in Zivil- und Handelssachen (I926 ff.); first volume also English, edited by Sturges (I928).

${ }^{104}$ Tabellen zum internationalen Recht. Heft $x$. Zivilprozess (Civil Procedure) (2d ed. I93r); Heft 2. Staatsangehörigkeit (Nationality) (I926); Heft 3. Urheberrecht (Copyright) (r928); Heft 4. Wechselrecht (Bills of Exchange) (2d ed. r930). These works give, in tabular form, precise information on the laws of all countries.

ros Die Rechtsverfolgung im internationalen Verkehr, vol. I: Der Zivilprozess in den europäischen Staaten und ihren Kolonien (Civil Procedure in European Countries and their Colonies) (I930 ff.), vol. IV: Das Eherecht der europäischen Staaten und ihren Kolonien (Marriage Law in European Countries and their Colonies); vol. VIII: Internationales Privatrecht der europäischen und aussereuropäischen Staaten. Die Quellen des internationale Privatrechts. (Private International Law of European and Non-European Countries. The Sources); vol. IX: Das Recht der Vereinigten Staaten von Amerika. part r: Erbrecht und Nachlassbehandlung. Erbschaftsbesteuerung (The Law of the U.S. of America. Inheritance Law. Probate. Inheritance Tax).

${ }^{106}$ Rechtsvergleichendes Handworterbuch für das Zivil- u. Handelsrecht des In- und Auslands, edited since $x_{927} 7$ under the direction of Franz Schlegenberger. Its first volume contains concise surveys of the private law systems of all countries of the world written by experts from the respective countries; the following volumes contain in encyclopedic arrangement comparative essays on single topics written by German lawyers, not all, of course, of the same value, but remarkably improving in the course of time.

${ }^{207}$ Cf. esp. the debates of the $34^{\text {th }}$ and $35^{\text {th }}$ "Deutsche Juristentag" (Cologne, I926; Lübeck I93 $\mathrm{x}$ ), where it was discussed how far Anglo-American experiences can be made use of for the reform of the German corporation law.

${ }^{\text {ro8 }}$ Cf. the series: Das Zivilprozessrecht der Kulturstaaten (Civil Procedure of Civilized Countries), edited by Wacht, Kisch, Mendelssohn Bartholdy and Pagenstecher; hitherto published (A. Heusler, Switzerland [1923]) Klein, Austria (1927); Wrede, Sweden and Finland (I924); also Rühl-Fragistas, Rechtspolitische und rechtsvergleichende Beiträge zum zivilprozessualen Beweisrecht (I929).

${ }_{\text {rog }} \mathrm{Cf}$. the series: Kartell- und Konzernrecht des Auslands, published by $\mathrm{H}$. Isay, hitherto published, I. Maneaud, France (I927); 2. F. E. Koch, England (I927); 3. C. Nádas, Hungary (I928); 4. de Sanctis, Italy (r928); 5. Hexner, Czechoslovakia (xg29). Also Lammers, Die Kartellgesetzgebung des Auslandes (I927); Isay in Zeitschrift für ausländisches und internationales Privatrecht IV. I. ff. Fischer-Wagenführ, Kartelle in Europa (I929), and the current reports on foreign legal developments in the Kartell-Rundschau (Ig03 ff.).

${ }^{1 r 0}$ Cf. v. Lambsdorff in Zeitschr. für ausländisches und internationales Privatrecht. vol. 4, p. 47I; osteuropaisches Institut: Das Pachtrecht in den europäischen Ländern. (2 vols. x929, I930).

xx Many reports on foreign legislation and doctrine in "Steuer $u$. Wirtschaft" (Ig2I ff.) and in "Vierteljahresschrift für Finanz- u. Steuerrecht" (I927 ff.).

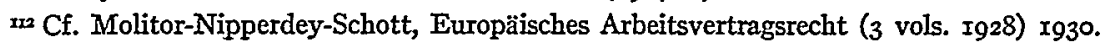


should be mentioned. Foreign material is of particular importance in the new matters of radio law, ${ }^{\mathrm{rr} 3}$ of air law, ${ }^{\mathrm{xx}}$ of film law, ${ }^{\mathrm{rr5}}$ of automobile law, etc. In all these fields, foreign legislation, foreign business practice, and foreign case law are eagerly watched and used for Germany's own purposes.

\section{V}

The branch of the law, which is perhaps most strongly influenced by the comparative law method, is Private International Law (Conflict of Laws), ${ }^{\mathrm{Ir} 6}$ where new suggestions were most urgently needed. At the beginning of the Igth century, the old theory of statuta, handed down from the times of the Post-glossators, was definitely confuted by v. Wächter. ${ }^{\text {Ir7 }}$ Savigny's great work, ${ }_{2}^{\text {r18 }}$ which was considerably influenced by Story, ${ }^{\text {Ix9 }}$ had happily combined the systematic sense of the pandectists with delicate casuistic sensitiveness. The conflict problems were not to be solved by some $a$ priori doctrines, but by carefully investigating, where a legal relation has its "center of gravity." Thus the ways for the future development of German conflict of laws were definitely settled. ${ }^{x 20}$ They were never forgotten by the courts, and, save for some deviations of no great

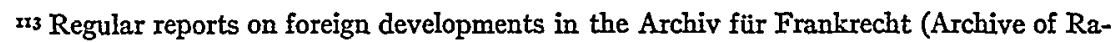
dio Law. I92I ff.).

14 Archive of Air Law, I93 If fi. continuing the Review of Air Law, I927/28.

325 Archive of Copyright Film Law, and Theatre Law (r928 fi.).

${ }^{n 16}$ The two terms are used here interchangeably, although the fields of Anglo-American Conflict of lan and German Internationales Privatrecht do not completely coincide. In strict meaning Internationales Privatrecht only deals with collision rules. Jurisdiction of courts and other topics of civil procedure form the subject of International lazv of Civil Procedure, which is sometimes dealt with in the same book with International Private law. Likewise, International Criminal Law, International Taxation Law, and International Administrative Law (standard work: Karl Neumeyer, Internationales Verwaltungsrecht, 3 vols. I930) are regarded as separate subjects. The use of the German words Internationales Recht carries with it to the German mind no such meaning as is conveyed in English by the term International law, for the branch of law, which is in English often called International Law, is called in Germany Law of Nations (Volkerrecht). But everybody agrees that the term International Private Law is very inadequate. Recently, the term Law of Collisions (Kollisionsrechi) is gaining ground.

French Droit international privê has another meaning since the French authors generally deal under this subject not only with collision rules, jurisdiction and matters of criminal law, and civil and criminal procedure, but also with nationality (dealt with in Germany in constitutional law) and with the general legal situation of foreigners (treated in Germany in administrative law (police!) or in international administrative law). The French term also indicates a connection with Droit international public (International law).

${ }_{117}$ Archiv für die zivilistische Praxis. 24.230, 25.I, I5I, 36I (I84I, I842).

${ }^{18}$ System des heutigen römischen Rechts. vol. VIII (r849); English ed. by Guthrie (1869, 2d ed. $\mathrm{r} 880$ ).

rg Cf. the remark on p. $I$ of the English edition.

$\approx 0$ Cf. M. Gutzwiller, Der Einfluss Savignys auf die Entwicklung des internationalen Privatrechts. I923. 
influence, legal doctrine, as well, always reverted to them. Ludwig v. Bar continued Savigny's sound methods. ${ }^{\text {II }}$ But after the Civil Code had come into force, his works became antiquated. ${ }^{\mathrm{I22}}$ The Civil Code itself states in its Introductory Law, some rules as to particular conflict problems, ${ }^{123}$ rather incompletely. The great bulk of conflict problems was left to doctrine and practice. Doctrine did not find much time and showed little interest. The pre-war years produced, besides some annotations of the scarce statutory rules, ${ }^{\text {124 }}$ only one single great treatise, Zitelmann's two volumes. ${ }^{\mathrm{x} 2}$ Starting with $a$ priori conceptions, and in a method similar to that of the French internationalists, he attempted to develop a conflicts system of alleged universal force based on International Law principles. It was a great undertaking, imposing in its subtlety and logical consistency, but it represented a conflict of laws system which was in force nowhere except in the ingenious brain of its author. The idea of developing a universal conflict system on International Law foundations was doomed just as was the attempt to start in a deductive method from a few natural law maxims postulated by the author. The work remained without influence on practice, and also in doctrine it found, fortunately, no great echo. Monographic literature was likewise scarce. Only a few books were of real importance: Karl Neumeyer's historical research into medieval conflict law, ${ }^{\mathrm{x} 26}$ Franz Kahn's oversubtle studies on general problems of the conflict of laws especially on review and qualification. ${ }^{x 27}$ The courts, insufficiently guided by doctrine, were groping. The whole picture was not very satisfactory.

How pressing the need was for a comprehensive treatise on the actual law, is shown by the fact that a treatise by an Austrian author, Gustav

${ }^{12 x}$ Theorie und Praxis des internationalen Privatrechts. 2 vols. 1889 , Lehrbuch des internationalen Privat- u. Strafrechts (1892).

122 He modernized them in the short surveys in Holtzendorff-Kohler's Enzylilopädie der Rechtswissenschaft. vol. II (I9I4), 223 ff., and in Ehrenberg's Handbuch des gesamten Handelsrechts. vol. I (xgI3), 327 ff.

${ }^{123}$ Articles 7-30.

$\times 24$ Neumann, Internationales Privatrecht in Form eines Gesetzentwurfs (1896); Baraseth, Das internationale Privatrecht im BGB (I897); Niemeyer, Das internationale Privatrecht des BGB (I9०I); Niedner, Kommentar zum Einführungsgesetz (rgor); Habicht, Internationales Privatrecht nach dem Einführungsgesetz zum Bürgerlichen Gesetzbuch (I907); remarkable: Neubecker, Deutsches internationales Privatrecht, in Jahrbuch für den internationalen Rechtsverkehr (I9I2, I9I3) 8.

225 Internationales Privatrecht (1897, 1912).

${ }_{226}$ Die gemeinrechtliche Entwicklung des internationalen Privat- u. Strafrechts bis Bartolus (2 vols. rgor, rgr6).

${ }_{27}$ Collected and re-edited by $O$. Lenel and H. Lewald under the title, Abhandlungen zum internationalen Privatrecht ( 2 vols. I928). 
Walker, ${ }^{\mathrm{x} 28}$ which appeared shortly after the war and which stated those rules of German and Austrian conflict law, which were sufficiently clear, was to be published within a brief period in three new editions. ${ }^{129}$

The short, but clear Outlines by Karl Neumeyer, ${ }^{130}$ opened the German post-war literature on International Private law, which now counts not less than nine more or less comprehensive treatises on Private International Law, accompanied by a rich monographic literature. In I926, Ernst Frankenstein, a Berlin lawyer, published the first volume of his treatise, conceived on a large scale and intended to comprise three big volumes. ${ }^{\mathrm{x} x}$ Although it is still rooted in the older period, in so far as the author attempts to build up a logical system, founded upon a few $a$ priori natural law maxims, and of universal force, the book announced a change, since it not only develops an ideal system constructed by the author, but also the law really being in force, which, however, Frankenstein not seldom denounces as regrettable deviations. But, nevertheless, the reader is led to the positive sources, not only of German but also of foreign law, especially to a great mass of case law. The work is ambiguous. The author feels himself obliged to observe the living law itself. $\mathrm{He}$ is an experienced international lawyer. He knows the problems with which practitioners are faced. And yet, he cannot free himself of the imposing model of the French deductive method. Also, Max Gutzwiller's International Private Law ${ }^{\mathrm{T} 32}$ was still influenced by the French school, although, in general, it is more markedly positivistic, and strictly regards the German conflicts rules as parts of the domestic German law.

Hans Lewald's book, ${ }^{\mathrm{x} 33}$ published in I93 I, definitely turned to a new method, since it deals with the German conflicts rules "on the basis of decided cases." The author is convinced of the futility of any attempt to build up a system of Private International Law upon a few axioms postulated $a$ priori. "I rather start with the conviction expressed by Mendelssohn Bartholdy with reference to International Criminal Law: That we must bring down the conflict rules from the heaven of concepts to the soil where alone they can grow vigorously, the soil of positive laws and of the facts of real life. Non ex regula ius sumatur, sed ex iure quod est regula fiat." Lewald has collected some thousands of decisions of German

I28 I92r. $\quad{ }^{29} 4$ th ed. I926.

${ }^{x_{30}}$ Internationales Privatrecht (2d ed. 1930 ).

${ }^{33}$ Internationalen Privatrecht (Ist vol. x926, 2d vol. I928).

${ }^{133}$ Internationalprivatrecht (1930), published in Stammlers' new encyclopedia, Das Gesamte Deutsche Recht $152 \mathrm{I}$ ff., and also as a separate reprint.

${ }_{33}$ Das deutsche internationale Privatrecht auf Grundlage der Rechtsprechung (r93r). 
courts, and he extracts therefrom the underlying rules. He demonstrates how German courts have built up, in a procedure of trial and error, but with a sound insight into the essence of the problems, a veritable system of case law. He presents it to the reader, critically and showing ways for future development. The book is a milestone in German Private International Law, in that it finally adopts the inductive, realistic method. Lewald deals only with German law, not with comparative law, at least not consciously. But we may rightly state, that Lewald would not have written it, had he not been deeply familiar with foreign conflict laws, especially with the French system.

Frankenstein had referred to foreign law in order to construct out of it, together with German law, an imaginary ideal system. Leo Raape, ${ }^{{ }^{34}}$ Arthur Nussbaum, ${ }^{\mathrm{I35}}$ and Martin Wolff ${ }^{\mathrm{r} 6}{ }^{36}$ use foreign conflict laws for another purpose. They deal with German private international law, Nussbaum also with Austrian and Swiss law. The statutory rules of these laws are full of gaps, the case law is often confused, but the problems are the same as they appear abroad. Thus, foreign conflict laws, their doctrines and decisions are used in the same manner as foreign laws are used in German substantive law, as sources for suggestions and comparison. Their works demonstrate, how successfully this can be done. In the same method foreign conflict laws are used by George Melchior in his remarkable treatise on the basic principles of German Private International Law. ${ }^{\mathrm{x} 7}$

Since I929, de Lapradelle and Niboyet started to edit a great French Cyclopaedia of Private International Law, ${ }^{\mathrm{r} 38}$ to which many scholars of various countries contributed systematical treatises of their respective conflict laws. The German Cyclopaedia of Comparative Law likewise deals with the conflict of laws, but it treats the conflict rules of all countries comprehensively in comparative method by arranging the subject matter systematically according to problems. ${ }^{\text {.39 }}$

${ }_{34}$ Annotations to the Introductory Law in Staudinger's Kommentar zum BGB (gth ed. vol. VI part 2. I93I); cf. also the short annotations by K. Th. Kipp in Fischer-Henle-Titze, Bürgerliches Gesetzbuch (I4th ed. I932), and Geiler's exposition of International Commercial Law (prepared by the Institute of Foreign and International Private law) in the Ist vol. of Diuringer-Hachenburg's Kommentar zum Handelsgesetzbuch (3d ed. x930).

x35 Deutsches Internationales Privatrecht (r932). $\quad{ }^{136}$ Internationales Privatrecht (I933).

${ }_{37}$ Die Grundlagen des Deutschen Internationalen Privatrechts, published 1932 by the Institute of Foreign and International Private Law.

${ }^{x} 3^{8}$ Répertoire de droit international (ro vols. I929-I93r).

${ }^{339} 4$ Rechtsvergleichendes Handwörterbuch (1932) 320-542. (A. N. Makaroff, Eduard Wahl, Ernst v. Cämmerer, Max Rheinstein, Hans G. Ficker, Martin Wolff, Hans-Joachim Veith, Hans Lewald, Walter v. Simson). 
One possibility of applying comparative law to Private International Law is to compare the conflict rules of various countries to each other, and to used foreign legal thought for refining their own conflict rules. A second possibility is pointed out by Ernst Rabel and Robert Neuner. To explain it, it is necessary to deal shortly with some basic ideals of Private International Law as it is conceived today in Germany. The older doctrine, represented by Savigny and his followers, regarded it as the task of Private International Law to connect "legal relations" with a certain country. Similar to the still prevailing Anglo-American doctrine, it spoke of "recognition of foreign-created rights" or of the application of a certain law to a certain "legal situation." German doctrine is now in the process of freeing itself from such conceptions. A right, a legal relation cannot exist outside a given body of law by which it is created. Whether it exists or not, we cannot know before having applied a certain law. The rules of conflict of laws are not at all essentially different from any other rules of law, since they determine how given situations of life are to be judged in the light of the law. Every rule of law, no matter of what kind, be it of private law, of criminal law, of constitutional law, or what else, consists of two parts: the "operative facts" and their "consequence in law." Where a certain situation is given in the world of facts and there arises a litigation, it ought to be juridically judged in such and such a way, or, to express it in the usual juridical metaphors, such and such legal consequences are to ensue therefrom. For instance, where two persons of certain qualities have agreed in a certain manner to exchange a certain thing for a certain sum of money, and if one of these two persons does not stick to the agreement-operative facts-he ought to pay damages-legal consequence. Where somebody takes away from another a thing which is assigned to the latter by certain rules of law with the intent to keep it and to deal with it as his own, he ought to be punished in such and such a way. Where the persons "elected" in a certain procedure and assembled in a certain manner in two bodies, called by a certain document the Senate of the United States and the House of Representatives of the United States, have agreed in a certain procedure by majority vote on a certain text, ordering certain persons to pay certain sums of money at certain times to other certain persons appointed as "officials" of the United States by a certain man, "elected" in a certain procedure "President" of the United States, and where this same man has also approved this text in a certain form, it shall be binding, and whosoever will not pay the certain sum of money (taxes) at the certain time, ought to be urged to do so by certain means of coercion. Conflict rules are not different, only that they do not 
state legal consequences immediately affecting individuals, but they only refer us to a certain body of rules which, in their turn, will state such legal consequences. They are, to use the German technical term, "law application rules" (Rechtsandwendungsnamen), ${ }^{\mathrm{I} 40}$ similar to the rules of Intertemporal Law. Just as no legal question can be decided without constitutional law being in the background and stating whether a purported rule has really binding force in law, be it, whether a statute be constitutional, or whether a precedent emanated from a court constitutionally empowered to state binding rules, so there is no conceivable question of private law without conflict of laws standing in the background and stating, out of which of the many legal systems of the world the rule deciding the case in question is to be taken. And just as constitutional questions become acute in comparatively rare border cases, the conflict question is to be dealt with consciously only where the case, that is the given situation of life, involves some "international element." But where a court applies its own substantive law without having expressly stated before that, according to their conflict rules, their own domestic law is to be applied, this is done because the law-application-rule in the background orders them to apply to pure domestic sets of facts their own domestic law.

Conflict rules must lay particular stress upon the local elements of the life situation which cause the litigation to be decided. The ideal conflict rule would be framed in such terms that it would use as "operative facts" just pure facts. In practice this cannot be done. It is still less possible than in the rules of domestic laws (cf. the examples given above). A conflict rule using pure facts would have to be expressed in such a complicated form, that it would be unmanageable. Legal terminology must use shorthand terms comprehending certain typical combinations of facts, viz. legal concepts. We scarcely can imagine a conflict rule not including in its "operative facts" such legal concepts. As a matter of fact, we observe that Private International Law is accustomed in all countries to use for this purpose, without much consideration, the concepts used in their own domestic law. Just as we use in our German conflict rules the terms Unerlaubte Handlung, Rechtsgeschäft, Verein, Entmündigung, Uneheliches Kind, Adoption, etc., Anglo-American conflict rules speak about trusts, corporations, conjugal rights, decedent estates, etc., and they use all these terms with the meaning they have in the substantive rules of the Common

${ }^{140}$ They find the justification for their existence in the desire that the mere accidental fact, before which country's courts a case will come for decision, ought to influence as little as possible the outcome of the decision. In framing conflict rules, this basic idea should never be lost sight of. 
Law. This natural tendency is strengthened by the attitude referred to above, according to which conflict of laws has to deal with "rights," "legal situations." To apply such terms, which are taken from a certain system of law, is unobjectionable, as long as we have to deal exclusively with conflicts between various bodies of law inside of one single legal system, e.g., between various statuta of medieval Italian cities, between various French coutumes, between various laws of the ancient Dutch provinces, between various jurisdictions inside the Common Law. Diffculties arise if we have to deal with laws belonging to different legal systems, e.g., between modern German and modern French law, or between a Common Law jurisdiction and a European law. If the conflicts rule uses in its operative facts terms borrowed from the domestic law of the forum, it no longer fits. Thus e.g., conflict rules of the European continental states make a sharp distinction between real and personal (obligatory) rights. How can a rule which is framed in such terms be applied to a litigation which is concerned with an Anglo-American trust, a phenomenon standing in the middle between real and personal rights? AngloAmerican conflict rules dealing with a deceased person's property are invariably framed with reference to the Anglo-American personal-representative-system. How are they to be applied to the inheritance of a person who was domiciled in a country whose inheritance law is built upon other foundations? ${ }^{\mathrm{x} 4 \mathrm{I}}$

How can we apply the rule stated in section 321 of the Restatement, ${ }^{x^{42}}$ if an American court has-incidentally-to decide, who, after the death of a German citizen domiciled in Germany, has become the owner of the chattels left by him? Or, if a law belonging to the Common Law system wants to protect a testator's widow or children against arbitrary testamentary dispositions, it must only reckon with the relation of the widow or the children to legatees. But how is the conflict rule of section 323 of the Restatement, ${ }^{\mathbf{1} 3}$ framed according to such a situation, to be applied, if, under the law of the deceased's domicile, third persons may not only be appointed legatees, but also instituted as universal successors? German Private International Law contains provisions with respect to the effects

I4r The difficulties arising out of such situations form one part of the so-called theory of qualification, so much discussed in Europe. It is expounded by E. Lorenzen, The Theory of Qualifications and the Conflict of Laws, in 20 Col. L. Rev. 247 (I920).

${ }^{142}$ "At the death of the owner of chattels, the title to the chattels passes to the executor or administrator appointed by the court of the state in which the chattels are habitually kept." (Proposed Final Draft No. 4, 1934.)

${ }^{243}$ "The right of a widow, child, or other person to a share of the personal estate in preference to legatees is determined by the law of the state in which the decedent died domiciled." 
of a foreign Todeserklärung (declaration of presumed death) of a disappeared person, ${ }^{\mathrm{x} 44}$ viz. of a decree of a court according to which a person who has disappeared is, with respect to his legal relations, to be presumed dead. But suppose that a foreign law does not know a "declaration of presumed death" but only a "declaration of absence," producing not identical but only similar effects to the German declaration of death? German law gives rules on the recognitions and the effects of foreign divorce decrees. ${ }^{\mathrm{X}} \mathrm{5}$ What if in a foreign country marriage is dissolved not by decree of a court, but as, e.g., in some rare cases in Sweden ${ }^{14^{6}}$ by an act of an administrative authority, or as in Soviet Russia, ${ }^{x}{ }^{x 7}$ by the mutual agreement of the parties, or, as in Quebec, ${ }^{\text {I48 }}$ by an Act of Parliament? We see, that the conflict rules are everywhere too narrow because they all start from the concepts of their own respective domestic laws.

When conflicts between laws of various systems become more frequent, it is necessary to break with such a method. Conflicts rules must be framed in such terms that they can embrace the laws of all civilized nations. This is Rabel's new postulate. ${ }^{\mathrm{I} 9}$ Its fulfilment is only possible through comparative law. If we want to know, whether the operative facts of a conflict rule not only cover the legal institutions of the lex fori, but that it really fulfils its task to choose between all the laws of the world, then we must know these laws beforehand. This is a wide field of applied comparative law of great practical importance.

We must proceed slowly, regarding the legal phenomena of one system after the other, and thus gradually adapt our conflict rules. ${ }^{\text {.50 }}$

I44 Introductory Law Art. 9. $\quad$ 145 Code of Civil Procedure $\$ 328$.

${ }_{4_{4}^{6}} \mathrm{Law}$ of November 12 th, I9x5, $\$ \S 4$ and 7 .

${ }^{147}$ Russian Socialist Federated Soviet Republic Code on Marriage, Family and Guardianship, of November Igth, I926, Art. ro.

${ }^{4} 4^{8}$ British North America Act, 1867 (30 Vict. c. 3) Sect. 9I, n. 26, Sect. x29.

${ }_{49}$ III Zeitschrift für ausländisches und internationales Privatrecht. (x929), 752, and esp. I Das Problem der Qualifikation (The Problem of Qualification), c. V. (I93I), 24I, also French in 28 Revue de droit international privé (I933), I, and Italian in Rivista italiana di diritto internasionale privato e processuale civile 2 (I932), 180.

${ }^{150}$ Conflict rules must be detached from municipal law concepts also in another respect, in the so-called "points of contact" (Anknitpfungsbegriffe). According to the Common Law conflict rule, e.g., a contract is generally governed by the law of the "place where it was concluded." It is usually taken for granted that the term "place of the conclusion of a contract" is to be defined by rules identical with those of municipal law. But, municipal law is interested in the conclusion of a contract in order to know at what time an agreement becomes binding in law. When the beginning of this effect is fixed at the moment where the offeree despatches his letter of acceptance, this does not mean that the same considerations which have led to this rule apply to the very different question of fixing the place of conclusion for the purpose of conflict 
Conflict rules are too narrow, but on the other hand, they are also too wide, where they differentiate too little in their contents, where they attempt, as existing conflict rules usually do, to embrace too many different sets of situations. "We cannot regard the conflict rules, as they are fixed by tradition or legislation, as a code covering all problems of Private International Law. It is impossible to derive from them deductively solutions for all possible problems. In domestic Private Law, nobody would think it possible to deduce from twenty or thirty rules the solutions of all problems. The abundance of our Private Law rules was developed from case to case during the centuries, especially by the Roman jurists, by seeking an appropriate solution in each given case. Roman jurists were masters in this very method, and the same method prevails in the Common Law. Nevertheless, Private Law still contains real gaps, a fact that is now probably universally acknowledged. The variety of situations is hardly less in Private International Law than in domestic law, for the differences between the various legal systems combine with the mass of situations to be regulated." "I5I We must therefore refine the traditional conflict rules in two respects. The operative facts must be more differentiated, e.g., there should not be one single conflict rule as to contracts, but quite a number of probably different rules for the various kinds of contracts. Conflicts rules will be different for contracts for the sale of goods-perhaps even such a rule will turn out to be too wide, for insurance contracts, for contracts of transportation on land and at sea, for contracts of brokerage, contracts for services, contracts for exchange transactions, etc.

of laws. It would certainly be very inconvenient in determining the law governing the formalities of contracting. When the conflict rules of many laws state that the formalities of a contract are governed by the law of the place where the contract is concluded (locos regit actum), this is done in order that the acting parties may know what formalities they have to apply in order to make their agreement legally binding. Therefore, the question must not be: $11 b i$ est negotium? but: ubi sunt qui agunt? (formulation by Leo Raape in Staudinger 6 Commentary on the Civil Code, part 2, [r78]). Considerations of such a nature lead to the need of distinguishing between the concept of place in the conflict rules and that concept in the municipal law rules as to the conclusion of contracts (cf. the survey on the theories developed in the various countries given by Rheinstein, 4 Encyclopaedia of Comparative Law, 368). Similar considerations apply to the concepts of "place of a wrong," used in municipal law principally to determine questions of venue. And even to the concept of domicile, which may have different meanings in taxation, in venue questions, in electoral law, in conflict of laws problems, etc. Not only the operative facts of the conflict rules but also the "points of contact" must be severed from municipal law concepts and be framed according to their own proper purpose.

Is Neuner, Der Sinn der internationalprivatrechtlichen Norm (The Meaning of the Private International Law Rule) (Brünn, I932), I3r. 
Another kind of differentiation will be necessary according to what legal systems are in conflict with one another. Private International Law frequently subjects the different aspects of a situation of life to different laws. Continental conflicts rules, for instance, distinguish, in regard to the conclusion of an agreement, first, the parties' capacity, which is governed by their respective personal laws; second, the formalities of the contract, which are generally governed by the lex loci contractus; and finally the question what sorts of agreements may have legally binding effect, which is governed by the "proper law of the contract." Or, upon a husband's death, the conflicts rules of many continental countries subject the question whether his widow is entitled to rights arising from matrimonial property relations to a different law than they do the question whether the widow is entitled to a share in the estate under inheritance law. Such a dépeçage can lead to results which would not occur, if the legal systems which are to be resorted to were to be applied in their entirety and not only in some parts. For instance, this is the case, ${ }^{\mathrm{r} 52}$ which caused Bartin to formulate his famous theory of qualification:153 A married couple who had been domiciled in Malta at the time of the conclusion of the marriage, moved to France. There they established a new domicile, and there the husband acquired certain immovables. What rights accrued to the widow after his death? According to French law, she would have been entitled to a certain share in the estate under the rules of the law of matrimonial property. Maltese law, as well, would give the widow a share, but it is doubtful whether this rule forms a part of Maltese inheritance law or of Maltese matrimonial property law. If it were to be treated as a part of the Maltese inheritance law, ${ }^{\text {I54 }}$ the widow would get nothing, because, according to French Private International Law, French courts have to apply Maltese matrimonial property law and French inheritance law, neither of which would give the widow any share! A strange result, apparently contradictory to both legal orders in question. In collisions of such a nature, the conflicts rules must be "qualified" so that we may reach a result which is in better harmony with the legal systems having application to the case. ${ }^{\text {Is5 }}$

Under Common Law conflict rules, the dépeçage is not so frequent, but it is not unknown. In American conflict law, matrimonial property relations as to chattels are generally governed by the law of the place where

\footnotetext{
152 Cour d'Appel, Alger, December 24th, I889; Journal Clunet I89I, II7I.

253 Etudes de droit international prive (1899), 68.

254 Actually the Court did not do so.

Iss Cf. Neuner l. c. p. $60 \mathrm{ff}$.
} 
the parties were domiciled at the time the chattels were acquired, ${ }^{156}$ whereas inheritance is governed by the law of the place where the decedent was domiciled at the time of his death. ${ }^{157}$ Here, similar difficulties may arise, as well as in consequence of the growing tendency to exclude the capacity of the parties from the law generally governing the conclusion of a marriage or of a contract, and to subject it to the law of the domicile of the party concerned. ${ }^{\mathrm{r} 8}$ Another typical example is furnished by the case of Hutchison 0 . Ross: ${ }^{\mathrm{I} 59}$ A married couple was domiciled in the Province of Quebec. There they had concluded a contract as to their property relations, securing a certain fund for the maintenance of the wife in case the husband should die before her. Later on, the husband, still being domiciled in Quebec, created a trust in New York for the benefit of the wife, "in lieu of" the rights accruing to the wife under the marital property contract, which were expressly waived by her. The husband's trustee in bankruptcy claims the trust fund asserting the invalidity of the trust. According to New York conflict rules, the New York court applied to the marital property relations the law of Quebec as the law of the marital domicile, to the creation of the trust the law of New York. The (French) law of Quebec declares any alteration of a marriage property contract invalid, with the consequence that, according to this law, the wife's waiver of the rights accruing to her under the contract was void, and consequently that she could not acquire any other rights, "in lieu thereof." On the other hand, the creation of the trust was in itself valid according to the New York law applicable to it. Thus, the Court was faced with the difficult problem, as to how New York law and Quebec law could be brought into accordance. The New York Court of Appeals evaded it, twisting the facts by interpreting the second agreement to the effect that the wife's waiver was independent of the creation of the trust.

In all such cases two or more laws must be applied side by side to one set of facts. Therefore, they must be attuned to one another. It is the task of the doctrine of conflict of laws to lead the courts in such cases, and in order to accomplish it comparative law is necessary. Such ideas come near to the opinions which were recently expressed in this country by Pro-

${ }^{25}$ Restatement, Conflicts (Prop. Final Draft No. 4. I934), § 3 rr.

157 Restatement, Conflicts (Prop. Final Draft No. 4. r934), $\$ \S 321,325,328$.

${ }^{258}$ Union Trust Co. v. Grosman, 245 U.S. 412 (IgI8); Beale, Laughlin, Guthrie, and Sandomire, Marriage and the Domicile, 44 Farv. L. Rev. 5 oI (I93I); Goodrich, Foreign Marriages and the Conflict of Laws, 2r Mich. L. Rev. 743 (1923); Baty, Capacity and Form of Marriage in Conflict of Laws, 26 Yale I. J. 444 (I9I7).

${ }_{259}$ Hutchison v. Ross, 262 N.X. 381, I87 N.E. 65 (I933), noted in 33 Col. L. Rev. I25I (I933); I Univ. Chi. L. Rev. 494 (I934); cf. also 32 Col. I. Rev. 37 I (I932). 
fessor Cavers. ${ }^{160} \mathrm{He}$ too demands that conflict rules should differentiate more and that the results should be different according to what laws are in conflict. At least, such an idea appears to be the underlying basis of his last article. However, there is certainly one difference between Professor Cavers and the German school. Professor Cavers would leave it to the courts to work out, in each individual case, the just and adequate solution, whereas Neuner would leave it to the legal scholar to reflect on such cases in advance and to propose the solutions to the courts. And certainly, the courts need guidance in this difficult field, where a peculiar method and a special knowledge are the indispensable elements with which practitioners and judges cannot be expected to be familiar.

VI

The new German science of comparative law has already achieved marked results: A wealth of knowledge of foreign laws and thereby a better understanding of foreign countries, enlarged facilities in international legal relations and thereby furtherance of foreign trade, preparation of material for legislation, far-reaching influences on the methods of domestic law in all its branches, a complete renovation of German Private International Law, and a vivification of International Law. If it is to come nearer to its ultimate goal, viz., to build up a comprehensive legal sociology on a positivistic basis, it needs collaboration with parallel tendencies abroad. Such a science is supernational like any social science. The field of its research cuts across political boundaries, and the research must be conducted in international co-operation.

Remarkable analogous achievements already exist abroad. In France, comparative law has been intensively cultivated already for a long time. ${ }^{16 \mathrm{r}}$ The works of Eduard Lambert have decidedly influenced modern comparative law methods, also in Germany. His and Paul Levy-Ullmann's works are outstanding examples of applied comparative law. Both men have trained a group of younger comparatists, who are successfully working especially in the fields of Anglo-American and of Mohammedan law. In Italy, two recently created Institutes, the Institute of Legislative Studies, and the League of Nations' Institute for the Unification of Private Law, both in Rome, are centers for comparative law research with theoretical and practical aims, around which a number of university institutes have been erected for the purpose of teaching. Professor Salvatore Galgano has founded a standard comparative law periodical of interna${ }^{160}$ David F. Cavers, A Critique of the Choice-of-Law Problem, 47 Harv. L. Rev. I73 (I933). ${ }^{26 x}$ Cf. above p. 237 . 
tional importance in the Annuario di Diritto Comparato, edited by the Institute of Legislative Studies. Dogmaticians of domestic Italian law are going to utilize comparative law for their own purposes. In England, the Comparative Law Association, publishing the Journal of Comparative Legislation, has been working in the field for many years. The London School of Economics, King's College, London, and other institutions of legal instruction have given comparative law a place in their curriculum. The University of Cambridge has established a new chair for comparative law. In the United States, as well, comparative law seems to find a regular place in the universities.

In I932, an international congress, which was perhaps planned on too large a scale, made a first attempt to bring together the comparatists from all countries. The large number of participants showed the great interest comparative law finds today. But on the other hand, the congress clearly revealed how much there is still to be accomplished. If the work is undertaken in as many places as possible, the net will grow tighter and the time may not be far when we shall have a real world-wide sociology of law, a science of the law as a social phenomenon.

Dogmatic treatment of the various laws of the various countries is everywhere certain to remain the main field of the lawyers and of legal science, but it will be fertilized by a comparative law science working beside it and co-operating with it, transcending the national borders and bringing into contact the jurists of all the world. 